\title{
Disposition of Isoniazid by Oral and Intravenous Administration in Cow Calf using RP-HPLC Method
}

\author{
Niranjan Bagal", Sushant Sole, Swati Umap, Ashwini Kambli and Kunal Kamble \\ Department of Veterinary Pharmacology and Toxicology, Mumbai Veterinary College, Parel, \\ Mumbai-400012, India \\ *Corresponding author
}

\section{A B S T R A C T}

In present experiment, Pharmacokinetic study of isoniazid (INH) was investigated in cow calf by using reverse phase high performance liquid chromatography (RP-HPLC) method.

\section{Keywords}

Isoniazid,

Pharmacokinetic,

Tuberculosis, High

Performance Liquid

Chromatography

(HPLC),

elimination Half-

life $\left(t_{1 / 2}\right)$, Mean

residence time

(MRT)

\section{Article Info}

Accepted:

12 August 2020

Available Online:

10 September 2020

The determination INH was carried out after oral and intravenous administration in cow calves at a dose of $25 \mathrm{mg} / \mathrm{kg}$ body weight orally and $10 \mathrm{mg} / \mathrm{kg}$ body weight intravenously. The blood samples of the animal receiving INH were collected at different time intervals of $15,30 \mathrm{~min}, 1,2,4,6,8,12,24$ and 48 hours for oral as well as intravenous administration. INH showed retention time of $5.8 \mathrm{~min}$ on using isocratic mobile phase made up of buffer (Sodium Dihydrogen orthophosphate $\mathrm{pH}-6$ ) and acetonitrile (96:4 ratio), with flow rate of $1 \mathrm{ml} / \mathrm{min}$ and C18 reverse phase column as used to detect INH at a wavelength of $265 \mathrm{~nm}$ after injecting $20 \mu \mathrm{l}$ of samples with Pyrazinamide used as the internal standard. Pharmacokinetic parameters of the present study were calculated using PK Solver program by applying the one-compartmental model. After oral and intravenous administration, the mean $\mathrm{C}_{\max }, \mathrm{T}_{\max }$, AUC (0-24 h), CL, $\mathrm{V}_{\mathrm{d}}, \mathrm{t}_{1 / 2}$ and MRT of isoniazid for oral administration were observed to be $0.64 \mu \mathrm{g} / \mathrm{ml}, 1.31 \mathrm{hrs}, 7.03 \mu \mathrm{g} / \mathrm{mL} * \mathrm{~h}$, $394.01(\mathrm{mg} / \mu \mathrm{g} / \mathrm{ml}) / \mathrm{h}, 4691.79(\mathrm{mg}) / \mu \mathrm{g} / \mathrm{ml}, 8.16 \mathrm{hrs}$ and $12.05 \mathrm{hrs}$, respectively while that for intravenous administration it was $1.48 \mu \mathrm{g} / \mathrm{ml}, 0.25 \mathrm{hrs}, 5.1 \mu \mathrm{g} / \mathrm{mL} * \mathrm{~h}, 168.45$ $(\mathrm{mg} / \mu \mathrm{g} / \mathrm{ml}) / \mathrm{h}, 566.68(\mathrm{mg}) / \mu \mathrm{g} / \mathrm{ml}, 2.42 \mathrm{hrs}$ and $3.49 \mathrm{hrs}$ respectively. By comparing the elimination $\mathrm{t}_{1 / 2}$ and MRT of INH by oral and intravenous route, it was observed that, the oral route of administration for INH was more convenient compared to intravenous administration. However, in view of acetylator status and age differences, the dose of 25 $\mathrm{mg} / \mathrm{kg}$ body weight for oral administration may also be reduced and further investigation on low dose can be carried out.

\section{Introduction}

Isoniazid,

also known

as

isonicotinylhydrazide (INH), is an antibiotic used for the treatment of tuberculosis. INH inhibits the synthesis of mycolic acid present in the cell wall of Mycobacterium species, which leads to cell death (Gumbo, 2016). India has the highest number of people affected by tuberculosis, accounting for more than one fifth of the global incidence. Tuberculosis is a contagious disease, caused by Mycobacterium tuberculosis mainly in humans. Zoonotic Tuberculos is caused by 
Mycobacterium bovis spreads through consumption of contaminated untreated meat or dairy products from diseased animals. In India, consumption of raw milk and living in close proximity to cattle has been attributed to high incidence rates of bovine tuberculosis in the central Indian populations. According to a research published in the journal of Epidemiology and Global Health, farmers, dairy workers, and zoo keepers were at greater risk (Annual Global Tuberculosis report, 2017 and Bapat et al., 2017).

The infection currently poses a major concern in human populations in developing countries, as humans and animals share the same microenvironment. It has been predicted that zoonotic transmission of Mycobacterium bovis is responsible for $10-15 \%$ of new human tuberculosis cases in developing countries (Ashford et al., 2001).

Affected animals are treated with INH and therefore it is important to generate the pharmacokinetic data of INH in cattle's. INH is commonly used in humans and animals by oral and intravenous route, but limited literature is available on pharmacokinetics of INH in bovine species, despite its wide scale use. Hence, in order to assess its absorption by oral and intravenous route and to establish pharmacokinetic data on INH, animal usage was necessary.

In view of above cited reports and unavailability of data in the context of pharmacokinetics of INH, the current study was designed with the aim to use this drug more confidently with proper dosage schedule in large animals.

\section{Materials and Methods}

\section{Animal experimentation}

The pharmacokinetic study of INH was planned in six months to one-year-old six cow calves of either sex in cross-over fashion. The average body weight of the cow calves ranged from 100 to $200 \mathrm{kgs}$. The animals were reared on ILFC, Bombay Veterinary College, Goregaon and only healthy calves, free from any sign of disease or disease conditions were selected. During the entire study period, the calves were kept isolated in a separate enclosure. Fresh concentrate and roughage mixture, and water were provided to the animals ad libitum. The animals were maintained separately for 2 months on the CPCSEA approved farm under a team of experienced veterinarians. After the experiment was over, the animals were made to join the rest of the flock after a thorough check-up. For using cow calves, the permission was obtained from IAEC (BVC/IAEC/22/2017) and CPCSEA (F. NO.25/31/2017-CPCSEA) respectively. The pharmacokinetics of INH was worked out after oral and intravenous administration using the doses that are currently being used by the practitioners while treating the animals for tuberculosis. Considering that the half-life of INH in human beings is six hours, blood samples were collected periodically till 48 hours.

INH powder was obtained as gift sample from Rajshi Chemicals and Products, Ghaziabad, Uttar Pradesh. For oral as well as intravenous administration, the INH solution was prepared by adding $0.9 \% \mathrm{w} / \mathrm{v}$ normal saline solution to obtain a final concentration of $50 \mathrm{mg} / \mathrm{ml}$ of INH.

Six healthy calves of 6 months to 1-year age were selected on the farm. They were dewormed using albendazole. After 10 days of anthelmintic administration, three of the calves received INH by intravenous route @ $10 \mathrm{mg} / \mathrm{kg}$ body weight and the other three calves were administered INH orally @ 25 $\mathrm{mg} / \mathrm{kg}$ body weight. After a gap of 15 days the same procedure of drug administration 
and blood collection and processing was repeated in crossover manner, i.e., the animals that received intravenous medication were subjected to oral INH administration and vice versa.

\section{Blood Sample}

The blood samples of the animal receiving INH were collected at time intervals of 15,30 min, 1, 2, 4, 6, 8, 12, 24 and 48 hours for oral and 15, $30 \mathrm{~min}, 1,2,4,8,12,24$ and $48 \mathrm{hrs}$ for intravenous administration. At each time interval, around 1-2 $\mathrm{ml}$ of blood was collected in vials coated with an anticoagulant i.e. EDTA and centrifuged at $10000 \mathrm{rpm}$ for 10 minutes to separate plasma.

\section{RP-HPLC Analysis}

HPLC analysis of INH was carried out by slightly modifying the method described by Indian Pharmacopeia (2007). INH showed retention time of $5.8 \mathrm{~min}$ on using isocratic mobile phase made up of buffer (Sodium Dihydrogen orthophosphate $\mathrm{pH}-$ 6) and acetonitrile (96:4 ratio), with flow rate of 1 $\mathrm{ml} / \mathrm{min}$ and $\mathrm{C} 18$ reverse phase column as used to detect INH at a wavelength of $265 \mathrm{~nm}$ after injecting $20 \mu \mathrm{l}$ of samples with Pyrazinamide (PZA) used as the internal standard. Extraction of plasma done by using methanol as the precipitant. Plasma $(0.18 \mathrm{ml})$ was taken into $5 \mathrm{ml}$ RIA tubes followed by addition of $0.01 \mathrm{ml}$ Internal Standard $(0.50 \mu \mathrm{g} / \mathrm{ml}$ of Pyrazinamide) and vortexed for 1 minute. Into the same tube $0.4 \mathrm{ml}$ Methanol and $0.2 \mathrm{ml}$ of Mobile phase was added to precipitate the plasma proteins and vortexed for another two minutes and centrifuged for ten minutes at $10000 \mathrm{rpm}$. After centrifugation, the supernatant $(400 \mu \mathrm{L})$ was separated and injected in HPLC. Pharmacokinetic parameters of the present study were calculated using one-compartmental model. The pharmacokinetic parameters were calculated by using PK Solver extension in Microsoft Excel 2016.

\section{Results and Discussion}

The analysis of INH was carried out by using HPLC method. HPLC analysis of INH was modified and carried out as per method described by Indian Pharmacopeia (2007). The calibration curve of INH was plotted in blank plasma in the concentration range from $1-10 \mu \mathrm{g} / \mathrm{mL}$. The method was found to be linear in the selected concentration range with regression coefficient of 0.9987 and slope and intercept values of 1.1093 and 0.0977 , respectively. The standard plot is depicted in Fig. 1, while standard chromatogram of INH depicted in Fig. 2 and standard chromatogram of INH and internal standard PZA depicted in Fig. 3.

The time-concentration curves of INH after oral and intravenous administration is presented in Fig. 4 and 5, respectively.

After oral and intravenous administration, the plasma INH concentration at different times and summary of the estimated kinetic parameters in Calves are presented in Table 1 and Table 2.

The mean $\mathrm{C}_{\max }, \mathrm{T}_{\max }$, AUC $(0-24 \mathrm{~h})$, clearance $(\mathrm{CL}), \mathrm{V}_{\mathrm{d}}, \mathrm{t}_{1 / 2}$ and MRT of isoniazid for oral $0.64 \mu \mathrm{g} / \mathrm{ml}, 1.31 \mathrm{hrs}, 7.03 \mu \mathrm{g} / \mathrm{mL} * \mathrm{~h}$, $394.01(\mathrm{mg} / \mu \mathrm{g} / \mathrm{ml}) / \mathrm{h}, \quad 4691.79(\mathrm{mg}) / \mu \mathrm{g} / \mathrm{ml}$, $8.16 \mathrm{hrs}$ and $12.05 \mathrm{hrs}$ after oral administration while for intravenous administration it was $1.48 \mu \mathrm{g} / \mathrm{ml}, 0.25 \mathrm{hrs}, 5.1$ $\mu \mathrm{g} / \mathrm{mL}^{*} \mathrm{~h}, \quad 168.45 \quad(\mathrm{mg} / \mu \mathrm{g} / \mathrm{ml}) / \mathrm{h}, \quad 566.68$ $(\mathrm{mg}) / \mu \mathrm{g} / \mathrm{ml}, \quad 2.42 \mathrm{hrs}$ and $3.49 \mathrm{hrs}$, respectively.

In present study, following oral administration of INH, with a dose rate of 25 $\mathrm{mg} / \mathrm{kg}$ body weight, the mean peak plasma concentration $\left(\mathrm{C}_{\max }\right)$ of $0.64 \mu \mathrm{g} / \mathrm{ml}$ was 
achieved at 1.31 hour i.e. $\mathrm{T}_{\max }$ (time to reach maximum concentration). This value lower than $1.85 \mu \mathrm{g} / \mathrm{ml}$ at 1 hours following an oral administration of INH at $10 \mathrm{mg} / \mathrm{kg}$ body weight in human (Conte et al., 2002). The difference in these values may be due to species as well as environmental differences. During this experiment, $\mathrm{C}_{\max }$ of $\mathrm{INH}$ in calves was observed at $\mathrm{T}_{\max }$ of 1.31 hour. This value of $\mathrm{T}_{\max }$ was lower than 2.5 hours as investigated in goats by (Nureen et al., 2011). Following oral dosing of $300 \mathrm{mg}$ total dose in patient suffering from antitubecular drug induced hepatotoxicity, the $\mathrm{T}_{\max }$ was 2.20 hour and $\mathrm{C}_{\max }$ was $4.09 \mu \mathrm{g} / \mathrm{ml}$ (Rath and Tevatia. 2016). However, (Jayaram et al., 2004) found that after $120 \mathrm{mg}$ dosing of $\mathrm{INH}$, $\mathrm{T}_{\max }$ was 0.16 to 0.5 hours. Bhandari and Kaur (2013) performed the study on rat, in which INH was given @ $25 \mathrm{mg} / \mathrm{kg}$ body weight orally. It was found that $\mathrm{C}_{\max }$ was 8.80 $\mu \mathrm{g} / \mathrm{ml}$, with $\mathrm{T}_{\max }$ was 1.54 hours. All these variations may be attributed to species differences as human beings have simple stomach whereas calves have rumen which is four stomach complex structure, which might have affected the absorption process.

In present study, AUC of INH after oral administration was $7.03 \mu \mathrm{g} / \mathrm{mL}^{*} \mathrm{~h}$, where as in rat AUC was $8.38 \mu \mathrm{g} / \mathrm{mL}^{*} \mathrm{~h} @ 30 \mathrm{mg} / \mathrm{kg}$ body weight (kumar et al., 2014).

In present experimental study, after oral administration of $25 \mathrm{mg} / \mathrm{kg}$ body weight INH in six cow calves, the mean of total body CL was $394.01(\mathrm{mg} / \mu \mathrm{g} / \mathrm{ml}) / \mathrm{h}$. almost similar value of CL $359(\mathrm{mg} / \mu \mathrm{g} / \mathrm{ml}) / \mathrm{h}$ has been observed in teddy goats after oral administration of $10 \mathrm{mg}$ per $\mathrm{kg}$ INH (Nureen et al., 2011). Apparent Vd of INH was $4691.79(\mathrm{mg}) / \mu \mathrm{g} / \mathrm{ml}$, whereas in rabbit $\mathrm{Vd}$ was $4290(\mathrm{mg}) / \mu \mathrm{g} / \mathrm{ml}$ after oral administration of INH (Walubo et al., 1991). However, lower value of $\mathrm{Vd} 600(\mathrm{mg}) / \mu \mathrm{g} / \mathrm{ml}$ reported in human after a single oral administration of $\mathrm{INH}$ (Boxenbaum and Riegelman, 1974). $\mathrm{t}_{1 / 2}$ and MRT of INH were found to be 8.16 hours and 12.05 hours, respectively. This value of $t_{1 / 2}$ was higher than 2.78 hours and 4.71 hours, respectively; as investigated in rats by Bhandari and Kaur (2013). Shorter half-life shows rapid elimination of drug and longer half-life indicates late elimination from the body. In pharmacokinetic study of INH and RMP in patients suffering from antitubercular drug induced hepatotoxicity, elimination half-life was 3.29 hours.

The difference in elimination half-life of INH in present study to other studies may be due to species difference. Elimination half-life of INH depends upon acetylator status of the animal towards the drug.

The inactivation rate, though constant in any one person, is known to vary from individual to individual and from race to race (Bhatia and Selkon, 1961).

In present study, following intravenous administration of INH with dose rate of 10 $\mathrm{mg} / \mathrm{kg}$ body weight, the mean peak plasma concentration $\left(\mathrm{C}_{\max }\right)$ of $1.48 \mu \mathrm{g} / \mathrm{ml}$ was achieved at 0.25 hour i.e. $\mathrm{T}_{\max }$ (time to reach maximum concentration). This value of $\mathrm{C}_{\max }$ was lower than $6.2 \mu \mathrm{g} / \mathrm{ml}$ at 0.67 hour following an intravenous administration of 5 $\mathrm{mg} / \mathrm{kg}$ body weight of INH in human (Saktiawati et al., 2015).

In present study, AUC of INH after intravenous administration was $5.1 \mu \mathrm{g} / \mathrm{mL}^{*} \mathrm{~h}$, were as in human AUC was $16.3 \mu \mathrm{g} / \mathrm{mL}^{*} \mathrm{~h} @$ $5 \mathrm{mg} / \mathrm{kg}$ body weight (Saktiawati et al., 2015).

In current investigation, apparent $\mathrm{Vd}$ of INH was $566.68(\mathrm{mg}) / \mu \mathrm{g} / \mathrm{ml}$. Lower value of $\mathrm{Vd}$ $300.02 \mathrm{mg} /(\mu \mathrm{g} / \mathrm{ml})$, were observed in rabbit after intravenous administration of INH (Walubo, et al., 1991). 
Table.1 Kinetic parameters after oral administration of Isoniazid at the dose level of $25 \mathrm{mg} / \mathrm{kg}$ body weight

\begin{tabular}{|c|c|c|c|c|c|c|c|c|c|}
\hline \multirow[t]{2}{*}{ Parameters } & \multicolumn{9}{|c|}{ Sample id-Oral } \\
\hline & $\underset{1}{\text { Animal }}$ & $\underset{2}{\text { Animal }}$ & $\underset{3}{\text { Animal }}$ & $\underset{4}{\text { Animal }}$ & $\underset{5}{\text { Animal }}$ & $\underset{6}{\text { Animal }}$ & Mean & SD & SE \\
\hline$C_{\max }(\mu \mathrm{g} / \mathrm{ml})$ & 0.82 & 0.69 & 0.9 & 0.6 & 0.59 & 0.29 & 0.64 & 0.21 & 0.08 \\
\hline $\mathbf{T}_{\max }(\mathbf{h r})$ & 1.48 & 1.34 & 1.28 & 1.16 & 1.49 & 1.14 & 1.31 & 0.15 & 0.06 \\
\hline AUC $\left(\mu \mathrm{g} / \mathbf{m l}^{*} \mathbf{h r}\right)$ & 9.52 & 8.68 & 7.3 & 6.95 & 5.69 & 4.06 & 7.03 & 1.98 & 0.80 \\
\hline clearance $((\mathrm{mg}) / \mu \mathrm{g} / \mathrm{ml}) / \mathrm{h})$ & 272.97 & 283.14 & 397.03 & 367.97 & 492.15 & 550.81 & 394.01 & 111.21 & 45.40 \\
\hline Vd $((\mathrm{mg}) / \mu \mathrm{g} / \mathrm{ml})$ & 3193.81 & 3909.58 & 2755.05 & 4544.26 & 4242.87 & 9505.21 & 4691.79 & 2449.45 & 999.98 \\
\hline T half(hr) & 8.1 & 9.57 & 4.8 & 8.56 & 5.97 & 11.96 & 8.16 & 2.55 & 1.04 \\
\hline MRT (hr) & 12.13 & 14.16 & 7.37 & 12,66 & 9.11 & 17.52 & 12.05 & 6.10 & 2.49 \\
\hline
\end{tabular}

(SD= Standard deviation; SE=Standard error; The INH administered to the 6 cow calves @ $25 \mathrm{mg} / \mathrm{kg}$ body weight by oral route, and sample were analyzed by RP-HPLC method)

Table.2 Kinetic parameters after intravenous administration of Isoniazid at the dose level of $10 \mathrm{mg} / \mathrm{kg}$ body weight

\begin{tabular}{|c|c|c|c|c|c|c|c|c|c|}
\hline \multirow{2}{*}{ Parameters } & \multicolumn{9}{|c|}{ Sample id-Intravenous } \\
\hline & $\underset{1}{\text { Animal }}$ & $\underset{2}{\text { Animal }}$ & $\underset{3}{\text { Animal }}$ & $\underset{4}{\text { Animal }}$ & $\underset{5}{\text { Animal }}$ & $\underset{6}{\text { Animal }}$ & Mean & SD & SE \\
\hline$C_{\max }(\mu \mathrm{g} / \mathrm{ml})$ & 1.6 & 1.55 & 1.57 & 1.38 & 1.49 & 1.28 & 1.48 & 0.12 & 0.05 \\
\hline $\mathbf{T}_{\max }(\mathbf{h r})$ & 0.25 & 0.25 & 0.25 & 0.25 & 0.25 & 0.25 & 0.25 & 0 & 0 \\
\hline $\mathbf{A U C}(\boldsymbol{\mu g} / \mathbf{m l} * \mathbf{h r})$ & 6.92 & 4.13 & 5.53 & 5.73 & 3.8 & 4.49 & 5.1 & 1.17 & 0.47 \\
\hline clearance $((\mathrm{mg}) / \mu \mathrm{g} / \mathrm{ml}) / \mathrm{h})$ & 118.46 & 199.63 & 148.99 & 143.48 & 216.69 & 183.46 & 168.45 & 37.48 & 15.30 \\
\hline$V_{d}((m g) / \mu g / m l)$ & 544.13 & 533.81 & 523.16 & 576.66 & 566.48 & 655.86 & 566.68 & 48.03 & 19.60 \\
\hline T half(hr) & 3.18 & 1.85 & 2.43 & 2.78 & 1.81 & 2.47 & 2.42 & 0.53 & 0.21 \\
\hline MRT (hr) & 4.59 & 2.67 & 3.51 & 4.01 & 2.61 & 3.57 & 3.49 & 0.76 & 0.31 \\
\hline
\end{tabular}

$(\mathrm{SD}=$ Standard deviation; $\mathrm{SE}=$ Standard error; The INH administered to the 6 cow calves at the dose rate of $10 \mathrm{mg} / \mathrm{kg}$ body weight by intravenous route, and sample were analysed by RP-HPLC method) 
Fig.1 Standard calibration curve of isoniazid in blank plasma

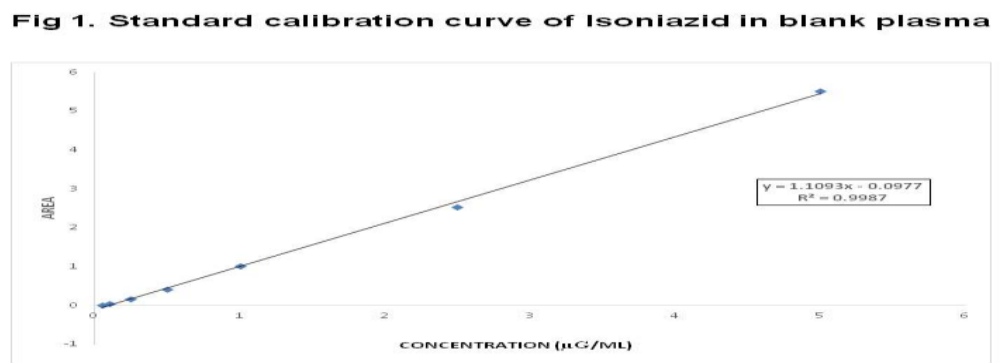

Fig.2 Standard chromatogram of isoniazid

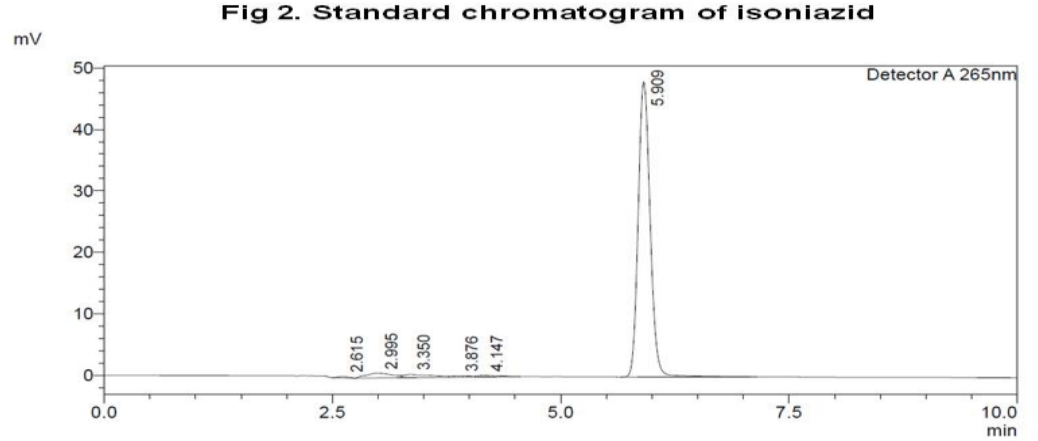

Fig.3 Chromatogram of drug and Internal standard

Fig 3. Chromatogram of drug and Internal standard

$\mathrm{mV}$




Fig.4 Time - Concentration curve of INH in Calves after oral administration at the dose rate of $25 \mathrm{mg} / \mathrm{kg}$ body weight

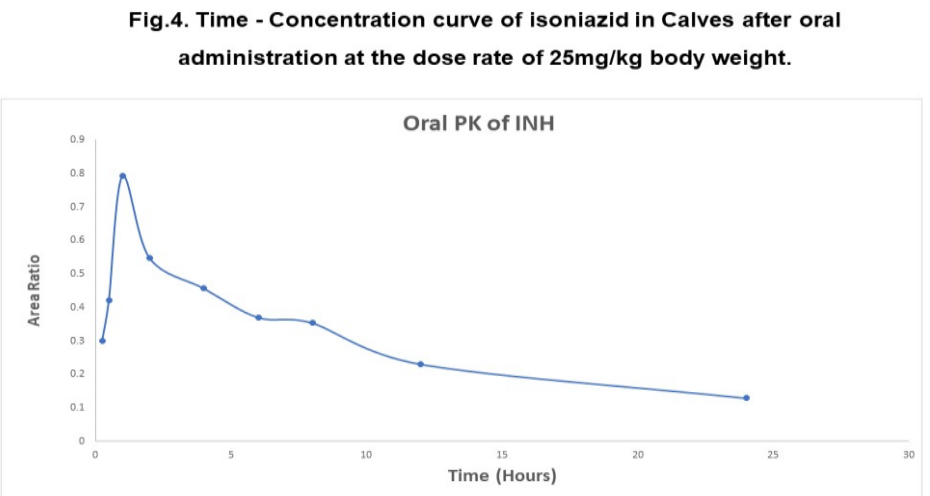

Fig.5 Time - Concentration curve of Isoniazid in calves after intravenous administration at the dose rate of $10 \mathrm{mg} / \mathrm{kg}$ body weight

Fig.5. Time - Concentration curve of isoniazid in calves after intravenous administration at the dose rate of $10 \mathrm{mg} / \mathrm{kg}$ body weight.

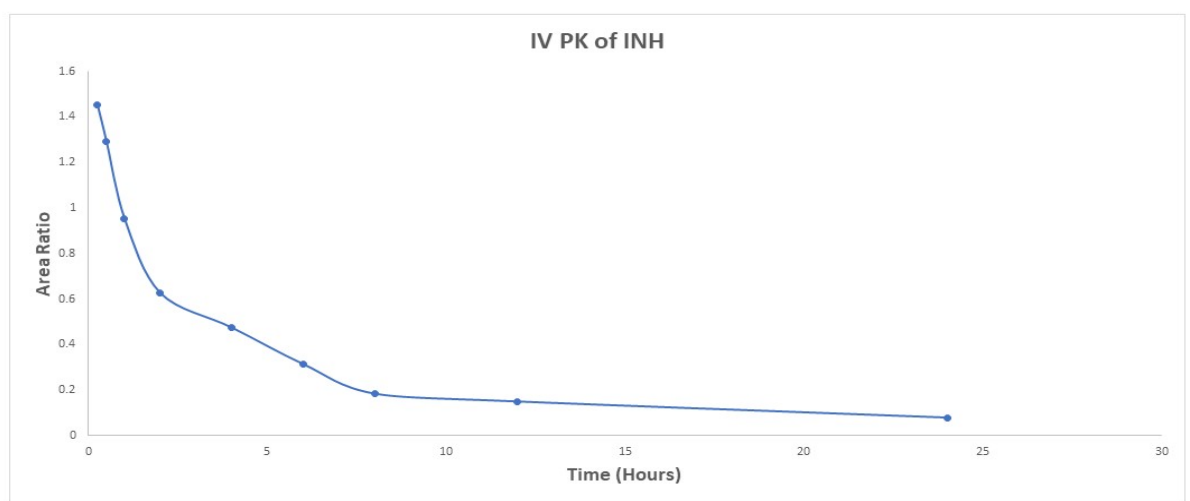

Comparing the elimination $t_{1 / 2}$ and MRT of $\mathrm{INH}$ by oral and intravenous route. It was observed that, the oral route of administration for INH will be more convenient compared to intravenous administration. Because, elimination $t_{1 / 2}$ and MRT of INH by oral administration were more as compared to intravenous route. However, in view of acetylator status and age difference the dose of $25 \mathrm{mg} / \mathrm{kg}$ body weight for oral administration may also be reduced and further investigation for the lower dose can be done.

In vivo concentration of $0.5 \mu \mathrm{g} / \mathrm{ml}$ is considered as generally accepted limit for bacteristasis (Kleeberg, 1966). The present results indicates that, the minimum inhibitory concentration (MIC) $0.48 \mu \mathrm{g} / \mathrm{ml}$ after oral administration was achieved up to $6 \mathrm{hrs}$ compared to intravenous administration, where in MIC noted was $0.5 \mu \mathrm{g} / \mathrm{ml}$. However, 
sharp decline MIC from $6 \mathrm{hrs}$ in case of intravenous administration compared to oral administration indicates that the steady state level after intravenous administration will be less than that of oral administration. In case of oral administration, the decline of MIC level was gradual. In view of the above comparison, as the steady state of MIC was observed for long time after oral administration than that of intravenous administration, which indicates oral route may be preferred route than intravenous administration.

Abbreviations: INH-Isoniazid, PZA Pyrazinamide AUC- Area under curve, $\mathrm{T}_{\max }$ Maximum time, $\quad \mathrm{C}_{\text {max }}$ Maximum concentration, $\mathrm{V}_{\mathrm{d} \text { - }}$ Volume of distribution, $\mathrm{t}_{1 / 2}$ -Half-life, MRT- Mean residence time, CLClearance, RP-HPLC- Reverse phase High Performance Liquid Chromatography)

\section{Acknowledgement}

The authors express their gratitude to Department of Veterinary Pharmacology and Toxicology, Mumbai Veterinary College, Mumbai for funding and supporting the research. The authors like to thank Dr. Rohan pai at Institute of Chemical Technology, Mumbai for constant support and guidance during entire research work.

\section{References}

Annual Global tuberculosis report. 2017. (www.who.int/tb/data).

Ashford, D. A., E. Whitney, P. Raghunathan and O. Cosivi. 2001. Epidemiology of selected mycobacteria that infect humans and other animals. Revue scientifique et technique (International Office of Epizootics), 20(1): 325-337.

Bapat, P. R., R. S. Dodkey, S. D. Shekhawat, A. A. Husain, A. R. Nayak, A. P. Kawle and S. Kashyap. 2017.
Prevalence of zoonotic tuberculosis and associated risk factors in Central Indian populations. J Epidemiol Glob Health, 7(4): 277-283.

Bhandari, R. and I. P. Kaur. 2013. Pharmacokinetics, tissue distribution and relative bioavailability of isoniazid-solid lipid nanoparticles. Int. J. Pharm, 441(1): 202-212.

Bhatia, A. L. and J. B. Selkon. 1961. "Rate of inactivation of isoniazid in South Indian patients with pulmonary tuberculosis." Bull. World Health Organ, 25(6): 765-777.

Boxenbaum, H. G. and S. Riegelman. 1974. Determination of isoniazid and metabolites and biological fluids. J Pharm Sci, 63: 1191- 1197.

Conte, J. E., J. A. Golden, M. McQuitty, J. Kipps, S. Duncan, E. McKenna. and E. Zurlinden. 2002. Effects of gender, AIDS, and acetylator status on intrapulmonary concentrations of isoniazid. Antimicrob Agents Chemother, 46(8): 2358-2364.

Gumbo T. 2016. Chemotherapy of Tuberculosis, Mycobacterium avium complex disease, and leprosy. Goodman and Gilmans the Pharmacological basis of therapeutics$12^{\text {th }}$ ed, page no. 1579 .

Indian Pharmacopoeia. 2007. Government of India. Ministry of health and family welfare, 2:1020-1.

Jayaram, R., R. K. Shandil, S. Gaonkar, P. Kaur, B. L. Suresh, B. N. Mahesh and V. Balasubramanian. 2004. Isoniazid pharmacokinetics-pharmacodynamics in an aerosol infection model of tuberculosis. Antimicrob. Agents Chemother, 48(8): 2951-2957.

Kleeberg, H. H. 1966. Chemotherapy and chemoprophylaxis of tuberculosis in cattle. Bibliotheca tub erculosea, 22: 189.

Kumar, N., K. G. Vishwas, M. Kumar, J. 
Reddy, M. Parab, C. L. Manikanth and R. K. Shandil. 2014. Pharmacokinetics and dose response of anti-TB drugs in rat infection model of tuberculosis. Tuberculosis, 94(3): 282-286.

Nureen, H., Z. Iqbal, J. Hasnain and A. A. Khan. 2011. Biodisposition of isoniazid after oral administration in teddy goats. Isra Medical Journal, 7 .

Rath, R. and S. Tevatia. 2016. Pharmacokinetic Study of Isoniazid and Rifampicin in Patients Suffering from Antitubercular Drugs (ATD) Induced Hepatotoxicity. J Bioequiv Availab, 8: 290-293.

Saktiawati, A. M., Sturkenboom, M. G.,
Stienstra, Y., Subronto, Y. W., Kosterink, J. G., Van der Werf, T. S. and Alffenaar, J. W. C. (2015). Impact of food on the pharmacokinetics of first-line anti-TB drugs in treatmentnaive TB patients: a randomized crossover trial. J. Antimicrob. Chemother., 71(3): 703-710.

Walubo, A., K. Chan and C. L. Wong. 1991. Simultaneous assay for isoniazid and hydrazine metabolite in plasma and cerebrospinal fluid in the rabbit. $J$ Chromatogr B Biomed Sci Appl, 567(1): 261-266.

\section{How to cite this article:}

Niranjan Bagal, Sushant Sole, Swati Umap, Ashwini Kambli and Kunal Kamble. 2020. Disposition of Isoniazid by Oral and Intravenous Administration in Cow Calf using RP-HPLC Method. Int.J.Curr.Microbiol.App.Sci. 9(09): 1577-1585.

doi: https://doi.org/10.20546/ijcmas.2020.909.197 